\title{
EVALUATION THE ACTIVITY OF ANTIOXIDANTS AND REPRODUCTIVE PERFORMANCE FOR ALLIUM CEPA AND ALLIUM SATIVUM EXTRACTS ON MALES RATS TREATED WITH MYCOTOXINS.
}

\author{
Dhia Hussain Jassim Al-Delemi ${ }^{1 *}$, Abeer Sami Kadhim ${ }^{2}$ \\ ${ }^{*}$ College of Veterinary Medicine \\ ${ }^{2}$ College of Biotechnology \\ *l,2 University of Al- Qadisiyah Iraq
}

*Corresponding Author: -

\begin{abstract}
: -
The present study has been designed to evaluate the beneficial effects of Allium cepa and Allium sativum extract upon Ochratoxin-induced hepatic toxicity, The study has been conducted on adult male rats during the period extended from February, 2017 to, July 2017. Fifty mature male Wister rats (aged 90 days and weighted $190 \pm 10$ g), were divided in to Five randomly equal groups, the first served as negative control received only normal saline, the second as positive control received with contaminated with Asp. niger in diet as a single dose $(2.5 \mathrm{mg} / \mathrm{kg} \mathrm{b.w).} \mathrm{third} \mathrm{group} \mathrm{received} \mathrm{with}$ contaminated with Asp. niger as a single dose then treated after 2 days with Allium cepa (250 $\mathrm{mg} / \mathrm{kg} \mathrm{b.w.)} \mathrm{respectively}$ orally through stomach tube during 42 days. fourth group received contaminated with Asp. niger as a single dose then treated after 2 days with Allium sativum (250 mg $/ \mathrm{kg}$ b.w.) respectively orally through stomach tube for 42 days. Fifth group received contaminated with Asp. niger as a single dose then treated after 2 days with Allium cepa and Allium sativum together $(250,250 \mathrm{mg} / \mathrm{kg} \mathrm{b.w.)}$ respectively orally through stomach tube during 42 days. males were anaesthetized (by injection i/p of $0.3 \mathrm{ml}$ ketamine $+0.1 \mathrm{ml}$ of xylazine $/ \mathrm{kg} \mathrm{b} . \mathrm{w}$. ip), blood samples were obtained from heart in non-heparinized tubes, Blood serum samples were separated for assessment of GOT, GPT, concentration, and assessment testosterone, FSH in blood serum. Under our experimental conditions, contaminated with Asp. niger resulted evidenced by statistically significant increase $(p>0.05)$ in the activities of GOT, GPT in group 2 of just Ochratoxin compared with the control group, while in the third and fourth groups showed statistically significant decrease ( $<<0.05)$ in GOT, GPT level in Blood serum of contaminated with Asp. niger treated group compared with the control group, while in assessment of hormone shown in contaminated group showed decrease of this hormones as for as in Allium cepa and Allium sativum groups increase in hormones and in combination groups was very high significant in hormones levels. After histological analysis of the group contaminated with Asp. niger proved change in the, after the gavage of (Allium cepa and Allium sativum), and in testicular section was shown the effect of plants extract to repair of tissue. The results showed that there was an improvement in liver tissues after treatment with Allium cepa and Allium sativum.

In present study we concluded to Allium cepa and Allium sativum together dose $250+250 \mathrm{mg} / \mathrm{kg} \mathrm{b}$.w. is better than dose $250 \mathrm{mg} / \mathrm{kg} \mathrm{b.w.} \mathrm{alone} \mathrm{depending} \mathrm{on} \mathrm{results} \mathrm{in} \mathrm{recently} \mathrm{study.} \mathrm{we} \mathrm{concluded} \mathrm{that} \mathrm{the} \mathrm{administration} \mathrm{of} \mathrm{(Allium} \mathrm{cepa} \mathrm{and}$ Allium sativum) together act as antifungal and antioxidant for contaminated with Asp. niger in males rats.
\end{abstract}

Keyword: - Allium cepa, Allium sativum, GOT, GPT, Testosterone and FSH.

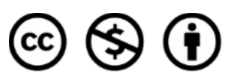




\section{INTRODUCTION}

Asp. niger has a great economical and biotechnological interest and is extensively used for production of extracellular enzymes and organic acids such as citric acid. [1,2] A. niger has even been granted the GRAS (Generally Regarded As Safe) status in certain industrial production processes by the Food and Drug Administration of the US government [3]. The discovery of $A$. niger strains producing OTA by.[4] raised concerns not only for their biotechnological safety but also for their food safety risk, due to their common presence in different commodities. [5,6,7] OTA is a potent nephrotoxin, hepatotoxicity and has teratogenic, immunosuppressive and carcinogenic properties. Cereals and cereal-based food and feed are the main contributors to OTA intake in humans and animals, since OTA is stable under normal food processing operation conditions and it is carried-over from raw materials to processed products [8]. Recently, however, these concerns may have widened. There are several reports stating that $A$. niger can also produce fumonisin B2(FB2-1)[9]. Onion (Allium серa) is one of the most commonly cultivated species of the family Liliaceae, and has long been used in dietary and therapeutic applications. Onions such as Allium cepa are rich in two chemical groups that have perceived benefit is to human health. These are the flavonoids such as quercetin and the alkenyl cysteine sulphoxides (ACSOs). Allium cepa has been reported to have medicinal potentials. Compounds isolated from onions have been shown to possess anticarcinogenic, hypolipidaemic, antithrombotic, antiasthmatic, antibacterial and antifungal properties [8,9]. A number of varieties of $A$. cepa are available commercially with varietal differences in phytoconstituents and biological activities.

Studies have also documented the antioxidant value of $A$. серa. Research has shown that onion contains exogenous and endogenous antioxidants such as selenium, glutathione, vitamins A, B, and C, and flavonoids such as quercetin and isorhamnetin. The antioxidant effect of $A$. cepa has been associated with reduced lipid Peroxidation index malondialdehyde (MDA) and increased superoxide dismutase (SOD), $[\mathbf{1 0 , 1 1 ; 1 2 ]}$.

Allium sativum is the largest and most prominent representative plant genus of the Alliaceae family and broadly cultivated in the northern hemisphere. Since ancient times, garlic (Allium sativum L.) has been used to cure diseases. The first citation of medical application of garlic as a remedy is found in the Codex Ebers (1550 B.C.), an Egyptian medical papyrus. Numerous therapeutic effects of garlic are largely attributed to (I) anti-diabetic, anti-atherosclerotic, antithrombotic, antihypertensive property (II) stimulation of immune function (III) detoxification (IV) hepato protection (V) anti-microbial and (VI) antioxidant effect $[13 ; \mathbf{1 4} ; \mathbf{1 5}]$. Nowadays, there is a worldwide increased interest regarding folk medicine. People desire to consume much more medical plants due to their medicinal properties. Garlic has abundant amount of antioxidants, flavonoids and sulfur-containing compounds [16] which can be used in detoxification systems [17]. Thiosulfinates are volatile sulfur garlic compounds responsible for pungent aroma, taste and biological effects [13].

\section{Material and method Plant material collection: -}

Allium cepa and Allium sativum plants were collected during 2017, from local market in AlDewanyia city.

\section{Preparation of Ethanolic Extracts (Malva parviflora and liqourice): -}

$20 \mathrm{gm}$ of Allium cepa and Allium sativum powdered were taken and extracted with soxhlet apparatus ethanol (70\%) for 24 hours, the extract placed in a petri dish and put in the oven at a temperature of $\left(40^{\circ} \mathrm{C}\right)$ for 48 hours and stored at $\left(4^{\circ} \mathrm{C}\right)$ until use [18].

\section{Experimental design: -}

Forty mature male wistar rats divided to five groups: - C: Ten mature male rats given normal saline for 42 days.

T1: Ten mature male rats received with contaminated with Asp.niger single dose for 42 days.

T2: Ten mature male rats received with contaminated with Asp.niger single dose and then treated after 2 days with Allium сера $(250 \mathrm{mg} / \mathrm{kg}$ b.w.) for 42 days.

T3: Ten mature male rats received with contaminated with Asp.niger single dose and then treated after 2 days with Allium sativum ( $250 \mathrm{mg} / \mathrm{kg}$ b.w.) for 42 days.

T4: Ten mature male rats received with contaminated with Asp.niger single dose and then mixed treated after 2 days with Allium cepa and Allium sativum (250+250 mg $/ \mathrm{kg}$ b.w.) for 42 days.

\section{Serum Preparation: -}

Blood was collected in test tubes and allowed to clot (for 20 minutes), then serum was separated by centrifugation at (4000 $\mathrm{rpm}$ ) for 15 minutes [19]. The separated serum of each animal was subdivided nearly into (6) samples using appendroff tubes $(0.5 \mathrm{ml})$ and kept at deep freezer $\left(40^{\circ} \mathrm{C}\right)$ until using for assessment of the biochemical parameters.

\section{Biochemical Assay GOT and GTP}

GOT and GTP are determinate by spectrophotometer (Biochemical test) to GOT and by using commercial kits (US bio, USA)

\section{ELIZA Assay}

Testosterone and FSH hormone determinate by ELIZA technique by by using commercial kits (US bio, USA)

\section{Microscopic examination}

Liver and Testis were excised and fixed in 10\%formalin neutral buffer solution. The trimmed tissues were first washed with tap water followed by dehydration through a graded alcohol series and then passed though xylol and paraffin series 
before being embedded in paraffin. The paraffin blocks were cut into 5-6 $\mu \mathrm{m}$ sections stained with Hematoxylin and Eosin and examined under a light microscope [20].

\section{Result Serum GOT concentration}

The results illustrated in figure (1) showed significant differences between all experimental groups and control group. In group T1 with gavage Ochratoxin showed significant increase $(\mathrm{p}<0.05)$ in serum concentration of GOT compared with control group, and in groups gavage with single dose of Ochratoxin and continuous gavage Allium cepa and Allium sativum daily (T2, T3) $(250 \mathrm{mg} / \mathrm{kg} \mathrm{B.W.)}$, showed significant decrease $(\mathrm{p}>0.05)$ in serum concentration of GOT compared with Ochratoxin group and in mixed groups(T4) $(250+250 \mathrm{mg} / \mathrm{kg} \mathrm{B}$.W.).

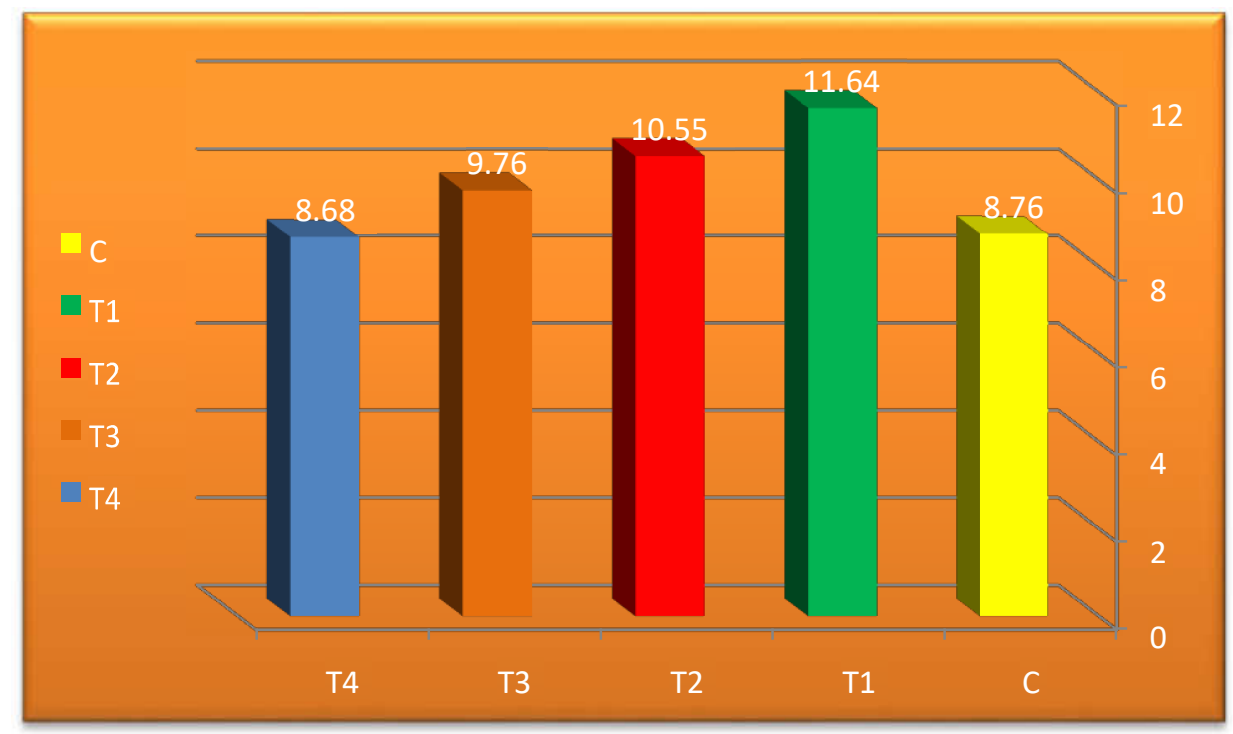

Figure (1): Effect of Allium cepa and Allium sativum treatment on serum GOT concentration $(\mu M o l e / m l)$ in mature male rats gavaged Ochratoxin.

\section{Serum GPT concentration}

The results illustrated in figure (2) showed significant difference between all experimental groups and control group. In group (T1) with gavage Ochratoxin showed significant increase $(\mathrm{p}>0.05)$ in the serum concentration of GPT compared with the control group, and in groups gavage with single dose of Ochratoxin and continuous gavage Allium cepa and Allium sativum daily $(\mathrm{T} 2, \mathrm{~T} 3)(250 \mathrm{mg} / \mathrm{kg} \mathrm{B}$.W. $)$ is showed significant decrease $(\mathrm{p}<0.05)$ in the serum concentration of GPT compared with the Ochratoxin group and in mixed groups(T4) $(250+250 \mathrm{mg} / \mathrm{kg} \mathrm{B}$.W.).

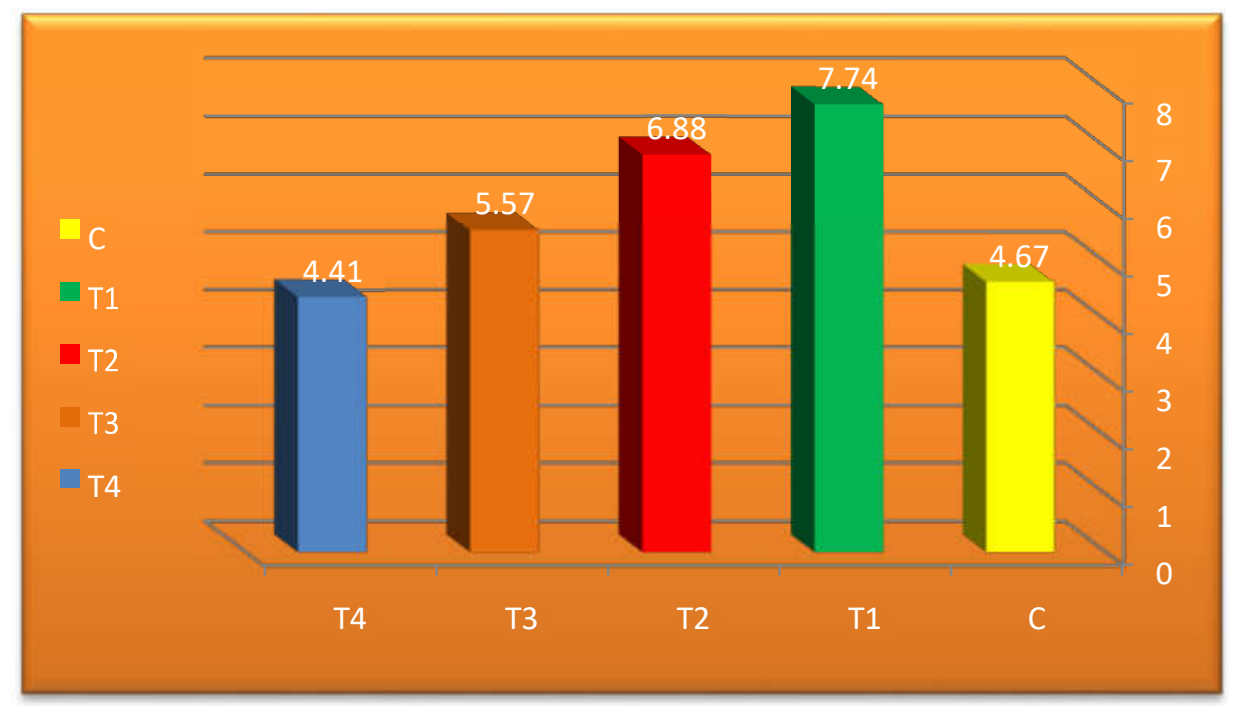

Figure (2): Effect of Allium cepa and Allium sativum treatment on serum GPT concentration ( $\mu$ Mole/ml) in mature male rats gavaged Ochratoxin.

\section{Serum Testosterone hormone concentration}

The results illustrated in figure (3) showed significant differences between all experimental groups and control group. In group T1 with gavage Ochratoxin showed significant decrease $(p<0.05)$ in serum concentration of hormone compared 
with control group, and in groups gavage with single dose of Ochratoxin and continuous gavage Allium cepa and Allium sativum daily $(\mathrm{T} 2, \mathrm{~T} 3)(250 \mathrm{mg} / \mathrm{kg}$ B.W.), showed significant increase $(\mathrm{p}>0.05)$ in serum concentration of hormone compared with Ochratoxin group and in mixed groups(T4)(250+250 mg/kg B.W.).

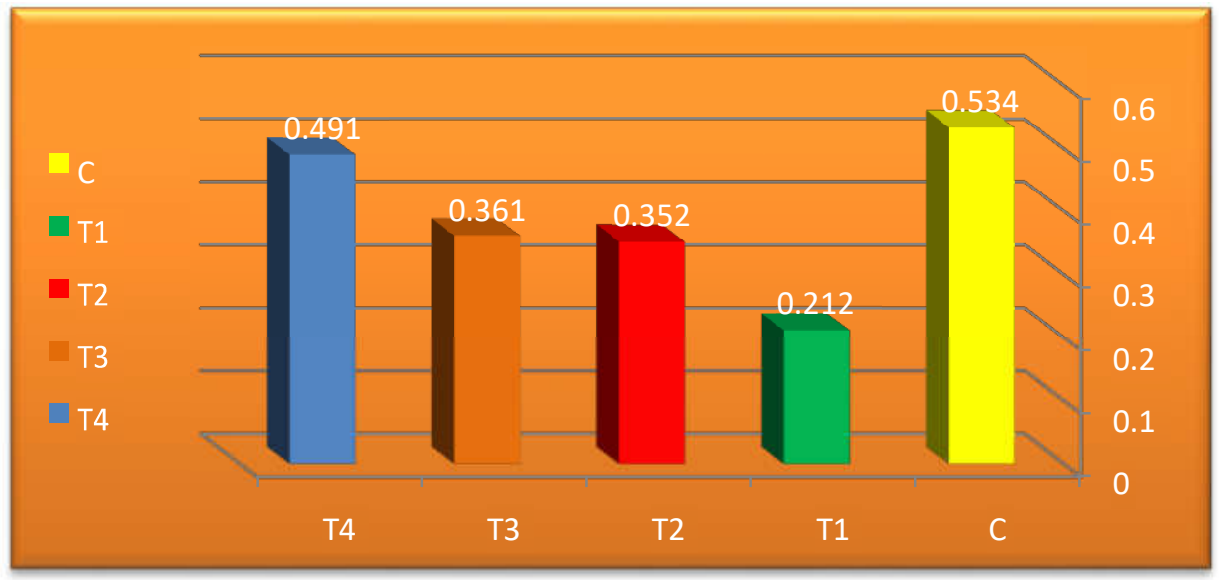

Figure (3): Effect of Allium cepa and Allium sativum treatment on serum Testosterone hormone concentration $(\mathrm{ng} / \mathrm{ml})$ in mature male rats gavaged Ochratoxin.

\section{Serum FSH hormone concentration}

The results illustrated in figure (4) showed significant differences between all experimental groups and control group. In group T1 with gavage Ochratoxin showed significant decrease $(\mathrm{p}<0.05)$ in serum concentration of hormone compared with control group, and in groups gavage with single dose of Ochratoxin and continuous gavage Allium cepa and Allium sativum daily $(\mathrm{T} 2, \mathrm{~T} 3)(250 \mathrm{mg} / \mathrm{kg}$ B.W.), showed significant increase $(\mathrm{p}>0.05)$ in serum concentration of hormone compared with Ochratoxin group and in mixed groups(T4)(250+250 mg/kg B.W.).

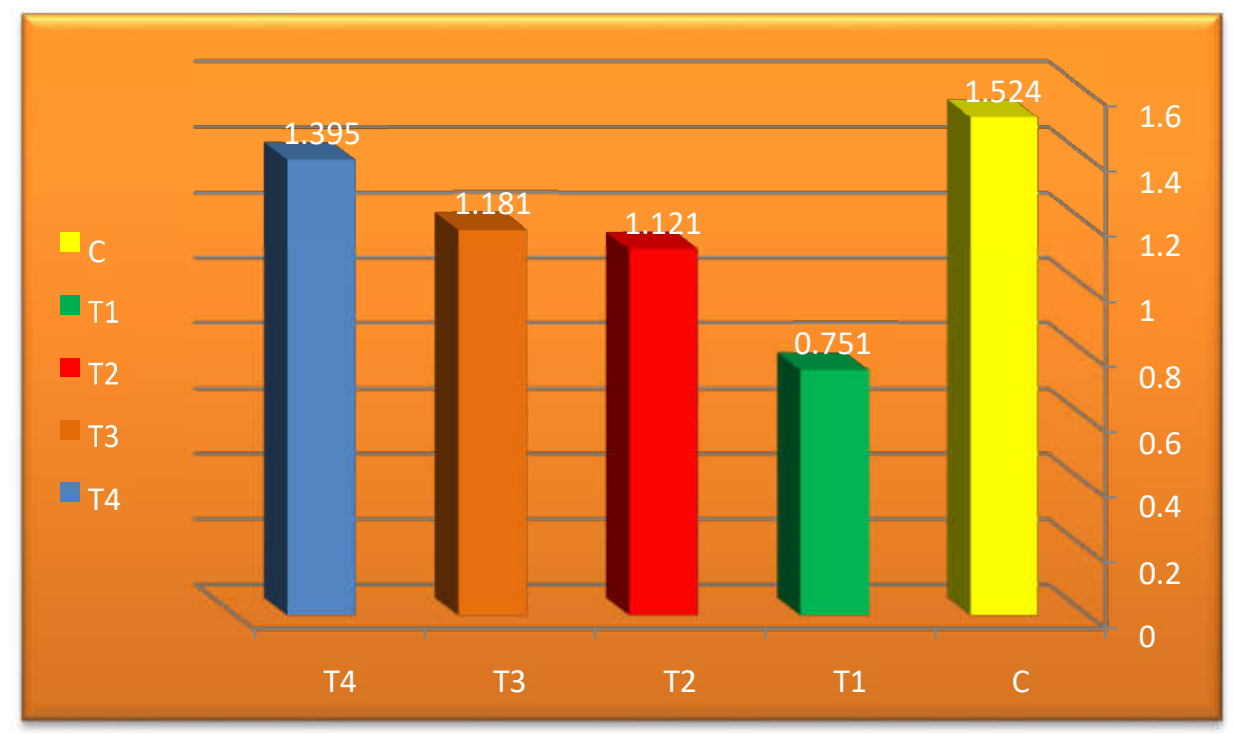

Figure (4): Effect of Allium cepa and Allium sativum treatment on serum FSH hormone concentration (U/ml) in mature male rats gavaged Ochratoxin. Histopathology profile

The sections obtained from liver of rats were explained of the many histological changes in tissue of liver in all groups of experiments, in control group was explain normal radial arrange around central vein and hepatocyte showed with hexagonal shape with acidophilic cytoplasmic and central permanent nuclei in liver tissue, whereas in Ochratoxin group was explained extensive necrosis in the hepatic tissue, loss of radially arrangement of hepatic cords around the central vein in liver tissue, congestion and hyper aplasia of bile duct in liver tissue. (Fig.5,6).

As for the Allium sativum group was explained some of cell showed bionuclatied, degeneration of hepatocyte, normal control vein , present of radial arrangement of hepatocyte and proliferation in liver tissue.(Fig.7,8).

As for the Allium cepa group was explained some of cell showed bionuclatied, degeneration of hepatocyte, normal control vein , present of radial arrangement of hepatocyte and proliferation in liver tissue (Fig9,10). And finally in Allium cepa\& sativum group was explained normal radial arrangement hepatocyte clear regeneration of hepatocyte which showed vacuolated and bionuclatid, mild dilation of cytoside in liver tissue.( Fig.11,12). 

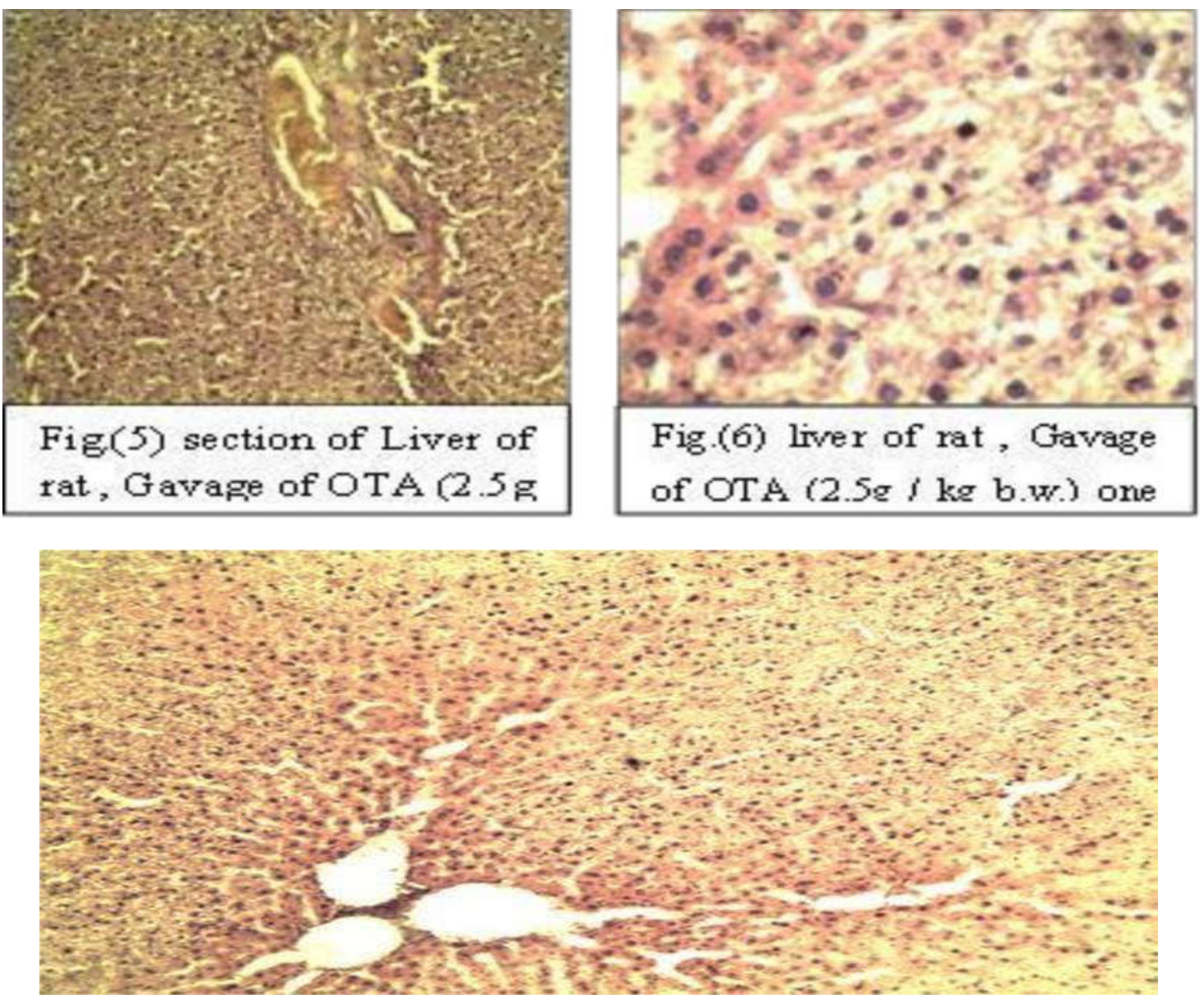

FIG. (7) liver of rat, Gavage of OTA (2.5g $/ \mathrm{kg} \mathrm{b.w.)} \mathrm{onetime} \mathrm{and} \mathrm{Gavage} \mathrm{of} \mathrm{sativum.} 250 \mathrm{mg} / \mathrm{kg} \mathrm{b.w.)} \mathrm{for} 42 \mathrm{days}$ .normal control vein, present of radial arrangement ofhepatocyte and proliferation in liver tissue. (H\&Ex10).

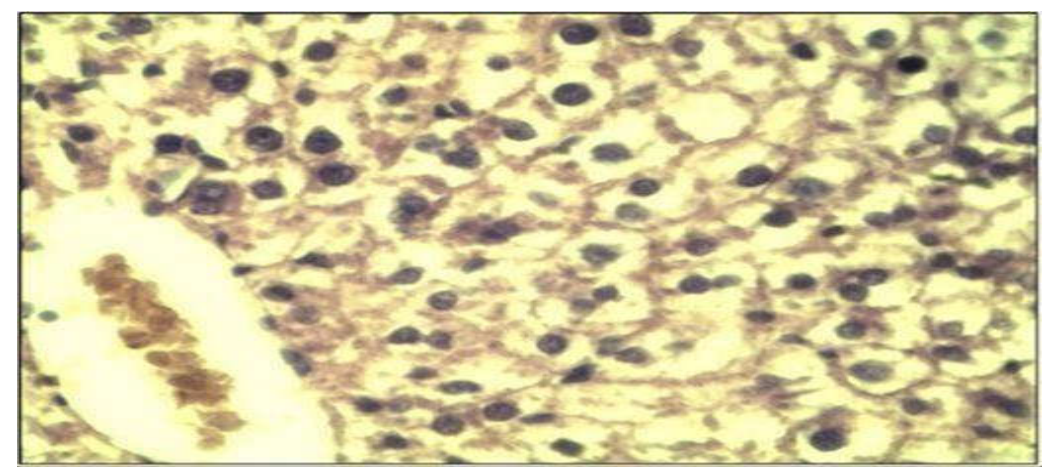

Fig.(8) Liver of rat, Gavage of OTA (2.5g / kg b.w.) onetime and Gavage ofsativum. 250mg/kg b.w.) for 42 days. normal radial arrangement hepatocyte In livertissue.(H\&Ex40)
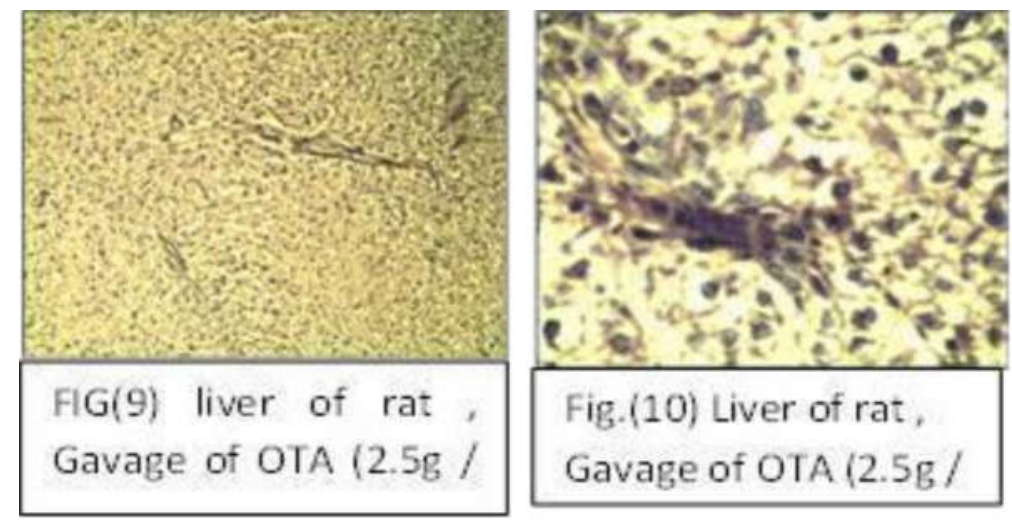


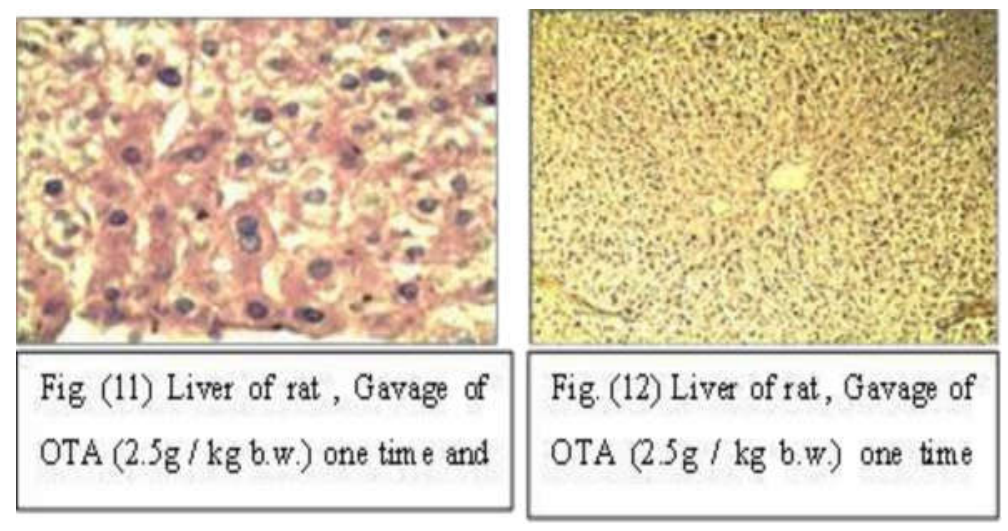

\section{Discussion}

The aim of this study was to investigate the protective effect of Allium cepa\& sativum on the Ochratoxin-induced liver toxicity and reproductive system evidenced by biochemical measurements of GOT and GPT levels in blood serum, testosterone hormone and FSH hormone levels in blood serum and histopathological changes. In fact, our study clearly demonstrates that effected of acute Ochratoxin on rats. In the present study, we found also that Ochratoxin-induced Liver damage by histological changes in liver of rat were explained of the many histological changes in tissue of liver in all groups of experiments, in control group was explain normal radial arrange around central vein and hepatocyte showed with hexagonal shape with acidophilic cytoplasmic and central permanent nuclei in liver tissue. whereas in Ochratoxin group was explained extensive necrosis in the hepatic tissue, loss of radially arrangement of hepatic cords around the central vein in liver tissue, congestion and hyper aplasia of bile duct in liver tissue. As for the cepa group was explained some of cell showed bionuclatied, degeneration of hepatocyte, normal control vein, present of radial arrangement of hepatocyte and proliferation in liver tissue.

And in the sativum group was explained some of cell showed bionuclatied, degeneration of hepatocyte, normal control vein, present of radial arrangement of hepatocyte and proliferation in liver tissue. And finally in cepa\& sativum group was explained normal radial arrangement hepatocyte clear regeneration of hepatocyte which showed vacuolated and bionuclatid, mild dilation of cytoside in liver tissue, and when we discussed the results in this study the effect of extract on regeneration of hepatocytes was very good as antioxidants activity and the extract is richen with the flavonoids, phenols and alkaloid this compound is very active to repair of tissues of liver and regeneration, also exerts antifungals properties and may participate to the defence against an oxidative stress by scavenging ROS [21,22]. Histopathological observations also substantiated the biochemical findings with improvements in Liver histology after administration of plant extract [23]. Other studies attribute the fall in the rate of plasma proteins caused by the administration of Ochratoxin to the poor efficiency of damaged livers to filter and reabsorb the protein [24]. In our work, two extract treatment effectively protected against Ochratoxin-induced hepatotoxicity by restoring almost normal activities of GOT and GPT. The attenuation of liver damage was confirmed by microscopic examination. These findings are in agreement with those reported earlier by others [24].

Previous studies showed that nutraceutical benefit of the extract of which plant have been attributed to the flavonoids, flavonols, and phenolics compounds $[23,24]$. The localization of flavonoids in the membrane interiors and their resulting restrictions on the fluidity of membrane components could strictly hinder the diffusion of free radicals generated during Ochratoxin oxidation, and there by decrease resulting damage effects [25]. Therefore, plants extract might play a key role in protection against Ochratoxin intoxication by modulating the cellular GSH pool [24]. In this regard, we suggest that plants exert an in vivo antioxidant activity against harmful reactive oxygen species generated following Ochratoxin oxidation, and could therefore prevent Liver damage.

Onion contains a wide variety of phytochemicals and micro constituents such as trace elements, vitamins, fructans, flavonoids, and sulphur compounds, which may have a protective effect against free radicals. Recently, much attention has been focused on the protective effects of onion against colon cancers in rats [17;26]. Some unique properties of onion such as antilipidaemic and antioxidant potentials have been studied [27;28;29]. Many studies were done to show Onion peels exhibited strong antioxidant activity and abundant phytochemicals and to elucidate their mechanism of action $[30 ; 31 ; 32$.]

Several factors have effect on very sensitive and complex process named spermatogenesis, and Lead to infertility or reduced fertility, The present results clearly indicate that Allium cepa has a good effect on spermatogenesis in rats. The biological activity of an extract of onion or garlic depends on its mode of preparation [33;34;27]. In the present study, the alcohol extract of onion was separately prepared. Quercetin, as a natural antioxidant, is ubiquitously distributed in fruits and vegetables. Onion is a rich source of quercetin [35.]

Reactive oxygen species play a physiological role on sperm maturation and capacitation while excessive generation of ROS is associated with DNA damage and sperm infertility [36]. Excessive ROS production and subsequent oxidative damage is the main mechanism of cadmium and chromium induced toxicity on spermatozoa [37]. Seminal plasma is endowed with frequent enzymatic antioxidants that include SOD, GPx, MDA [38]. ROS react with these enzymes via cell membrane lipid oxidative damage in sperm [39]. Based on the results, we think levels of satvium used in the current research were not sufficient to amplify SOD levels in rat semen. The method used to obtain garlic extract, as well as extracted preparation affects its biological activity [40]. In the current study, satvium contains water-soluble organosulfur 
compounds such as S-allylmercaptocysteine (SAMC), SAC, lipid-soluble allyl sulphides (DAS) and diallyl polisulphides (DADS) which have antioxidant properties [41]. Recently, antioxidants attract widespread attention in medicine research [15]. It is well documented that toxic metal cause oxidation [42]. Glutathione peroxidase is a lipid peroxidative antioxidative enzyme and its elevated activity is a biomarker for tissue damage. GPx is related to GSSG (reduced form of glutathione) and GSH (oxidized form of glutathione.)

In this present study the results are showed the plants extract activity antifungal and antioxidants by single dose from Allium cepa or Allium sativum, whereas in mixed extract are very good results as antifungal or antioxidants.

\section{Conclusion}

In the present study concluded the extracted of these plants (Allium cepa and Allium sativum) are considered very important plants as the activity on the toxic and as antioxidants in this study singly and mixed. And they effect on the toxic OTA this toxic is very important because this toxic is found in food and in the environment, to this we recommendation to more researchs on these plants.

\section{References}

[1].Abarca, M.L; Bragulat, M.R; Castell, G; Caba nes, F.J.(4991( . Ochratoxin A production by strains of Aspergillus niger var. niger. Appl Environ Microb. 60:2650-2.

[2].Baker, S.E.(2006) . Aspergillus niger genomics: past, present and into the future. Med Mycol. 44:S17-21.

[3].Schuster, E; Dunn-Coleman, N; Frisvad, J.C; van Dijck, PWM (2002). On the safety of Aspergillus niger a review. Appl Microbiol Biotechnol. 59:426-35.

[4].Perrone, G; Susca, A; Cozzi, G; Ehrlich, K; Varga, J; Frisvad, J.C, et al.(7002 ). Biodiversity of Aspergillus species in some important agricultural products. Stud Mycol. 59:53-66.

[5].Gautam, A.K; Sharma, S. Avasthi, S; Bhadauria, R.(7044( . Diversity, pathogenicity and toxicology of A. niger: an important spoilage fungi. Res J Microbiol. 6:270-80.

[6].Joosten, H.M.L.J; Goetz, J; Pittet, A; Schellenberg, M. Bucheli, P.(7004(. Production of ochratoxin A by Aspergillus carbonarius on coffee cherries. Int J Food Microbiol. 65:39-44.

[7].Lucchetta, G; Bazzo, I; Dal Cortivo, G; Stringher, L; Bellotto, D; Borgo, M; et al. (2010). Occurrence of black Aspergilli and ochratoxin A on grapes in Italy. Toxins. 2:840-55.

[8].International Agency for Research on Cancer (IARC). (4991 (. Some naturally occurring substances; food items and constituents, heterocyclic aromatic amines and mycotoxins. IARC monographs on the evaluation of carcinogenic risks to humans, vol. 56 ; p. 489.

[9].Logrieco, A; Ferracane, R; Haidukowsky, M; Cozzi, G; Visconti, A. (7009 ( Ritieni A. Fumonisin B production by Aspergillus niger from grapes and natural occurrence in must. Food Addit Contam Part A.; 26:1495-500.

[10]. Ige, S.F; Akhigbe, R.E; Adewale, A.A; Badmus, J.A; Olaleye, S.B; Ajao, F.O. (2011) . Effect of Allium cepa (Onion) extract on Cadmium-induced nephrotoxicity in rats. Kidney Res J; 1:41-7.

[11]. Guercio, V; Galeone, C; Turati, F;.La Vecchia, C. (2014). Gastric Cancer and Allium Vegetable Intake: A Critical Review of the Experimental and Epidemiologic Evidence. Nutr. Cancer: pp1-17.

[12]. Kumar,.A.; Borta, K.S.; Jaggi, A.S.; Shri, R.(2016). Comparative evaluation of neuroprotective effects of three varieties of Allium cepa in chronic constriction injury induced pain. Thai Journal of Pharmaceutical Sciences (TJPS), 40(1), January-March.31-704104

[13]. Lanzotti, V. (2006). The analysis of onion and garlic. J Chromatogr A, 111:23-22.

[14]. Bozcuk, H.; Ozdoğan, M.; Aykurt, O.; Topcuoğlu, F.; Ozturk, H.; Ekinci, D.;Karadeniz, A.;Mutlu, A.; Burgu cu, D. (2011). Urginea maritima (L.) Baker (Liliaceae) extract induces more cytotoxicity than standard chemotherapeutics in the A549 non-small cell lung cancer (NSCLC) cell line. Turk J Med Sci, 41:101108.

[15]. Khaki, A.; Farnam, A.; Davatgar, Badie, A.; Nikniaz, H. (2012). Treatment effects of onion (Allium cepa) and ginger (Zingiber officinale) on sexual behavior of rat after inducing an antiepileptic drug (Lamotrigine). Balkan Med J, 29:236-242.

[16]. Asadpour, R.; Azari, M.; Hejazi, M.; Tayefi, H.; Zaboli, N. (2013). Protective effects of garlic aquous extract (Allium sativum), vitamin $\mathrm{E}$, and $\mathrm{N}$-acetylcysteine on reproductive quality of male rats exposed to lead. Vet Res Forum, 4:251-257.

[17]. Ola-Mudathir, K.F.; Suru, S.M.; Fafunso, M.A.; Obioha, U.E.; Faremi, T.Y. (2008). Protective roles of onion and garlic extracts on cadmium-induced changes in sperm characteristics and testicular oxidative damage in rats. Food Chem Toxicol, 46:36043611.

[18]. Harborne, J. B. (1984). Phytochemical methods: A guide to modern techniques of plant analysis. 2PndP ed. Chapman and Hall New York. PP.1-4.

[19]. Laessig, R.H.; Westgard, J.O. and Carey, R.N. (1976). Assessment of a serum separator device for obtaining serum specimens suitable for clinical analyses. Clin Chem. 22:235- 239.

[20]. Lee, L.G. (1968). Manual of histologic staining methods for the armed force institute of Toronto, London, pathology 3rd ed., Mc Graw Hill book Company, NY, 12-31.

[21]. Srinivasan, C.; Williams, W.M.; Ray, M.B.; Chen, T.S. (7004 (. Prevention of acetaminophen-induced liver toxicity by 2(R, S)-n-propylthiazolidine-4(R)-carboxylic acid in mice.Biochem Pharmacol.;61(2):45-252.

[22]. Abdel-Zaher, A.O.; Abdel-Rahman, M.M.; Hafez, M.M.; Omran, F.M. (7002). Role of nitric oxide and reduced glutathione in the protective effects of aminoguanidine, gadolinium chloride and oleanolic acid against acetaminophen-induced heapatic and renal damage.Toxicology. 234(1-2):124-134. 
[23]. Massey, T.E.; Stewart, R.K.; Daniels, J.M.; Liu, L. (1995). Biochemical and molecular aspects of mammalian susceptibility to Aflatoxine B1 carcinogenicity, Proc. Soc Exp Biol Med. 208:213-227.

[24]. Lee, D.H.; Ha, M.H.; Christiani, D.C. (2001). Body weight, alcohol consumption and liver enzyme activity--a 4year follow-up study. Int J Epidemiol. 30:766-770.

[25]. Zafar, Iqbal, Shahzad; et al. (2014). "Natural incidence of ochratoxins, ochratoxin A and zearalenone in chicken meat and eggs". Food Control. 43: 98-103.

[26]. Prasad, A.S. and Oberleas, D. (1973). Ribonuclease and deoxyribonuclease activities in zinc-deficient tissues. J Lab Clin Med.; 82(3):461-6.

[27]. Corzo-Martinez, M.; Corzo, N.; Villamiel, M. (2007). Biological properties of onions and garlic. Food Sci. Tech., $18,609-625$.

[28]. Lewin, G.; Popov, I. (1994). Antioxidant effects of aqueous garlic extract. 2nd communication: inhibition of the $\mathrm{Cu} 2+$ - initiated oxidation of low-density lipoproteins. Arzneimittelforschung, 44, 604-660.

[29]. Prasad, K.; Laxadal, V. A.; Yu, M.; Raney, B.L. (1996). Evaluation of hydroxyl radical scavenging property of garlic. Mol. Cell. Biochem., 154, 55-63.

[30]. Rahman, K.; Billington, D. (2000). Dietary supplementation with aged garlic extract inhibits ADP-induced platelet aggregation in humans. J. Nutr.,130, 2262-2265.

[31]. Lau, B.H.S. (2001). Suppression of LDL oxidation by garlic. J.Nutr., 131, 985S-988S.

[32]. Dillon, S. A.; Burmi, R.S.; Lowe, G.M.; Billington, D.; Rahman, K. (2003). Antioxidant properties of aged garlic extract: an invitro study incorporating human low density lipoprotein.Life Sci., 72, 1583 - 1594.

[33]. Shashikanth, K.W.; Basappa, S.C.; Murthy, V.S. (1986). Effect of feeding raw versus boiled garlic (A. sativum L.) extracts on the growth, caecal microfl ora and serum proteins of albino rats. Nutr. Report Int., 33, 313-319.

[34]. Kleijnen, J.; Knipscnild, P.; Terriet, G. (1989). Garlic, onion and cardiovascular risk factors. A review of the evidence from human experiments with emphasis on commercially available preparations. Br. J. Clin. Pharmacol., 28, 535544.

[35]. McAnlis, G.T.; McEneny, J.; Pearce, J.; Young, I.S.(1999). Absorption and antioxidant effects of quercetin from onions, in man. Eur J Clin Nutr;53(2):92-6.

[36]. Hsieh, Y.; Chang, C.; Lin, C. (2006). Seminal malondialdehyde concentration but not glutathione peroxidase activity is negatively correlated with seminal concentration and motility. Int J Biol Sci, 2:23-29.

[37]. Marouani, N.; Tebourbi, O.; Mahjoub, S.; Yacoubi, M.T.; Sakly, M.; Benkhalif, M.; Rhouma, K.B.( 2012). Effects of hexavalent chromium on reproductive functions of male adult rats. Reprod Biol, 12:119-133.

[38]. Fingerova, H.; Novotny, J.; Barborik, J.; Brezinova, J.; Svobodova, M.; Krskova, M.; Oborna, I. (2007). Antioxidant capacity of seminal plasma measured by tas Randox. Biomed Pap Med Fac Univ Palacky Olomouc Czech Repub, 151:37-40 .

[39]. Chi, H.J.; Kim, J.H.; Ryu, C.S.; Lee, J.Y.; Park, J.S.; Chung, D.Y.; Choi, S.Y.; Kim, M.H.; Chun, E.K.; Roh, S.I. (2008). Protective effect of antioxidant supplementation in sperm-preparation medium against oxidative stress in human spermatozoa. Hum Reprod, 23:1023-1028.

[40]. Thomson, M.; Alnaqeeb, M.A.; Bordia, T.; Al-Hassan, J.M.; Afzal, M.; Ali, M. (1998). Effect of aqueous extract of onion on the liver and lung of rats. J Ethnopharmacol-14094,.99

[41]. Kim, S.; Lee, I.; Baek, H.; Moon, C.; Kim, S.; Kim, J. (2013). Protective effect of diallyl disulfide on cyclophosphamide-induced testicular toxicity in rats. Lab Anim Res, 29:204-211.

[42]. Akunna, G.G.; Ogunmodede, O.S.; Saalu, C.L.; Ogunlade, B.; Bello, A.J.; Salawu, E.O. (2012). Ameliorative effect of Moringa oleifera (drumstick) leaf extracts onchromiuminduced testicular toxicity in rat testes. World J Life Sci Med Res, 2:20-26. 